\title{
Article \\ Defence Is a Priority in Female Juveniles and Adults of Taxus baccata L.
}

\author{
Kinga Nowak ${ }^{1, * \mathbb{D}}$, Marian J. Giertych ${ }^{1,2} \mathbb{D}$, Emilia Pers-Kamczyc ${ }^{1} \mathbb{D}$, Peter A. Thomas ${ }^{3}$ and Grzegorz Iszkuło $^{1,2} \mathbb{C}^{\mathbb{D}}$ \\ 1 Institute of Dendrology, Polish Academy of Sciences, 62-035 Kórnik, Poland; \\ giertych@man.poznan.pl (M.J.G.); epk@man.poznan.pl (E.P.-K.); iszkulo@man.poznan.pl (G.I.) \\ 2 Faculty of Biological Sciences, University of Zielona Góra, 65-516 Zielona Góra, Poland \\ 3 School of Life Sciences, Keele University, Keele ST5 5BG, UK; p.a.thomas@keele.ac.uk \\ * Correspondence: knd@man.poznan.pl; Tel.: +48-613072423
}

Citation: Nowak, K.; Giertych, M.J.; Pers-Kamczyc, E.; Thomas, P.A.; Iszkuło, G. Defence Is a Priority in Female Juveniles and Adults of Taxus baccata L. Forests 2021, 12, 844. https://doi.org/10.3390/f12070844

Academic Editor: Stefan Arndt

Received: 30 March 2021

Accepted: 21 June 2021

Published: 26 June 2021

Publisher's Note: MDPI stays neutral with regard to jurisdictional claims in published maps and institutional affiliations.

Copyright: (c) 2021 by the authors. Licensee MDPI, Basel, Switzerland. This article is an open access article distributed under the terms and conditions of the Creative Commons Attribution (CC BY) license (https:// creativecommons.org/licenses/by/ $4.0 /)$.

\begin{abstract}
Female individuals of dioecious plants invest their resources more in storage and defence, and the males have higher nitrogen content invested in the production of pollen grains. An unresolved problem is whether this strategy occurs only in sexually mature plants or can also occur in juvenile plants. To answer this, Taxus baccata (L.) needles from the mature plants and rooted cuttings (juveniles) in a pot experiment were compared for the content of carbon, nitrogen, starch, total non-structural carbohydrates (TNC), and total phenolic compounds (TPhC). The results indicate that the differences between sexes occurred mainly in sexually mature plants, where the starch content was higher in females and nitrogen in males. However, the novelty of the results is that TPhC was generally higher in females than males in both adults and juveniles, suggesting that defence is a priority for females from an early age. We do not know if this is an innate trait because the strobili production (albeit at a very low level) of juveniles was observed in all individuals after the autumn of the first year. We found no effect of fertilization on sex-specific response in the pot experiment, which may be related to the lower reproductive effort of juveniles.
\end{abstract}

Keywords: dioecious plants; sexual dimorphism; Taxus baccata L.; total nonstructural carbohydrates; starch; phenolic compounds

\section{Introduction}

Dioecy is a relatively rare sexual system in land plants, found in about $6 \%$ of angiosperms [1-3]. However, it is the dominant system in gymnosperms, where nearly $65 \%$ of species are dioecious [4]. Dioecious plants are an interesting subject of research due to the clear division of sexual functions in individuals as well as being good models for studying plant strategies of resources allocation [5,6]. A general biological rule is that growth, maintenance, and reproduction compete for the same limited resources [7,8]; however, many different factors (plant age, habitat, and phenology) influence which trait receives most of them. This could offset life-history trade-offs among the sexes between growth and reproduction. Therefore, secondary sexual dimorphism (SSD), not directly related to the generative organs, is often observed in dioecious species [8]. SSD is pointed to as a consequence of reproductive inputs, and it may constitute an adaptation to fulfilling sexual functions [9]. These can be physiological mechanisms as well as differences in resource management $[10,11]$.

The generally accepted norm is that females invest more in generative structures, storage, and defence substances, and male individuals invest more in growth and nitrogen accumulation $[5,12,13]$. An outstanding question is whether this pattern appears in juvenile plants or is only present in adults. However due to difficulties in sex determination at the juvenile stages, until plants flower, limited data address this question [6]. It is known, however, that male and female seeds can differ in their response to environmental factors in their rate of germination [14], and it would seem therefore that dimorphism might also be 
expressed in other phenotypic traits early in the ontogenesis [9]. In the case of herbaceous Silene latifolia, sexual dimorphism was observed in resource allocation patterns after, but not before, investment in reproduction [15]. On the other hand, sexual dimorphism in growth was observed in pre-reproductive individuals of Siparuna grandiflora shrub but not among mature plants [16]. Moreover, in studies on Lindera benzoin, sex-differences in growth were observed in pre-reproductive stages, so it has been suggested that some of these trait differences may be present before flowering [17].

SSD can also be affected by habitat conditions; furthermore, in many cases, differences between sexes are present only under stressful conditions $[8,18,19]$. However, in other studies, female individuals make better use of available resources under fertile conditions $[20,21]$. Therefore, it is important to take into account the nutrient availability in research on the mechanisms of sexual dimorphism in dioecious plants.

Plant phenology (including growth and dormancy) can also affect the expression of SSD. Many studies have shown that phenological changes such as growth, flowering, fruiting, and dormancy can affect the differences in SSD [6,22-24]. This should lead to an understanding of the functional significance of specific trait differences [9].

The subject of research reported here was common yew (Taxus baccata L.), a dioecious shrub or a small tree. It is a very good model species in which to study dioecy because it is known to show SSD, such as higher growth rates in males [25], greater requirements for water in females [26,27], greater needle area of female specimens, greater nitrogen content of males [24], or greater sensitivity of females to light stress [28].

Observations of SSD are relatively easy to perform in the case of short-lived plants by comparing selected features before and after reaching sexual maturity. In the case of longlived organisms, such studies are very difficult to perform. One solution is propagation through cuttings taken from mature plants. This gives the possibility of a large number of plants of known sex and age, and it provides juveniles whose response to experimental conditions is not affected by reproductive effort. During vegetative reproduction, plants undergo a process of rejuvenation [29]. Moreover, vegetative reproduction is a common phenomenon, and $66.5 \%$ of species of central European plants exhibited clonal growth [30]. Cuttings have been used in a number of SSD research studies (e.g., [19,31-33]).

The novelty of this study is its use of both adults and vegetatively propagated juveniles, making it possible to compare plants at different stages of development. The research presented in this paper takes into account age, nutrient fertilization, and phenology. We focused on key chemical elements and compounds such as C, N, carbohydrates, and phenolic compounds. Determination of these is a useful method for identifying specific strategies of allocating resources to plants' growth, maintenance, and reproduction [34,35]. We hypothesized that: (1) in both adult and juvenile female individuals, a higher content of phenolic compounds and sugars and a lower content of nitrogen would be observed compared with males; (2) this content would change over time depending on phenology; and (3) SSD would be more visible in non-fertilized conditions.

\section{Materials and Methods}

\subsection{Plant Material}

The experiment was conducted at the Institute of Dendrology, Polish Academy of Sciences, in Kórnik, Poland. The study was divided into two parts: field studies on adult trees and a pot experiment on rooted cuttings sited $500 \mathrm{~m}$ apart.

\subsubsection{Field Study}

Twenty (10 males and 10 females) adult yews (Taxus baccata L.) grown at the Kórnik Arboretum, Institute of Dendrology PAS, Poland (52 $14^{\prime} 40.4^{\prime \prime}$ N $17^{\circ} 06^{\prime} 04.7^{\prime \prime}$ E), were selected. The trees were genetically different because they were a result of natural regeneration from seeds, and they were at least five meters apart. Plants were mature and had visible reproductive structures (male or female strobili buds and/or female arils). 


\subsubsection{Pot Experiment}

Rooted cuttings were obtained from the same individuals used in the field study. In 2012, fifty shoots of each maternal tree were collected and rooted in multiport trays. Similar size cuttings were taken from the middle part of each crown. In total, 1000 shoots were rooted ( 20 trees; 10 males and 10 females $\times 50$ shoots).

\subsection{Experiment Design}

\subsubsection{Field Study}

The study was conducted in the Kórnik Arboretum ( $\left.52^{\circ} 14^{\prime} 40.4^{\prime \prime} \mathrm{N} 17^{\circ} 06^{\prime} 04.7^{\prime \prime} \mathrm{E}\right)$, Poland. Ten male and ten female trees of similar height and diameter with visible reproductive structures (male or female strobili buds and/or female cones) were randomly chosen. Measurements of photosynthetically active radiation (PAR) carried out in accordance with the methodology described by Messier and Puttonen [36] showed that the mean reduction of sunlight was $53.1 \%( \pm 4.60 \mathrm{SE})$ and that the light reduction did not differ significantly between the sexes. One- and two-year-old needles were collected four times a year for two years. Samples were taken in 2014 and 2015, respectively in spring during the flowering period (March); in summer (June) after the end of the shoot growth; in autumn (September) during the maturation of seeds and arils, after the completion of the development of seeds and arils and the formation of buds for the next season; and in winter (December) during plant dormancy.

\subsubsection{Pot Experiment}

Cuttings were grown in $5 \mathrm{~L}$ pots under $2 \mathrm{~m}$ high scaffolding with shading net to produce a $50 \%$ reduction in full sunlight. The soil for the pots was obtained from a natural broadleaved forest, with $10 \%$ of the soil volume added from a stand of T. baccata. In March 2013, cuttings were divided into two blocks containing both sexes (Figures S1 and S2). Within each block, a fertilized group of seedlings received $6 \mathrm{~g}$ per litre of slow-release fertilizer Osmocote Exact 5-6M (ICL, Israel) in March 2014 and 2015, whereas the nonfertilized seedlings were grown without any additional fertilizer. The fertilizer contained $15 \% \mathrm{~N}, 9 \% \mathrm{P}, 12 \% \mathrm{~K}, 2.5 \% \mathrm{MgO}$, and microelements.

One- and two-year-old needles were collected four times a year for two years from three individuals in each treatment in the experiment (three individuals $x$ two fertilization treatments $\mathrm{x}$ two blocks $=12$ individuals per one term) at the times described above.

Any developing strobili in the juvenile cuttings were noted at each sampling period. The assumption of the experiment was to test individuals prior to reproduction in the first year of measurements, but most of them developed strobili very early. Therefore, sexually immature specimens were tested only in the spring and summer of the first year. However, a comparison of the abundance of strobili in mature individuals in the field studies and individuals in the pot experiment showed that the ratio of generative organ to needles and stems mass was several times lower in the juvenile plants than in mature individuals [37].

\subsection{Chemical Analyses}

Chemical analyses were conducted the same way for both field studies and pot experiment. All needles were separated from their respective shoots and used in downstream analyses. The content of total carbon, total nitrogen, total soluble phenolics, soluble carbohydrates, and starch were analysed in each sample. Samples were initially dried at $65^{\circ} \mathrm{C}$ for $72 \mathrm{~h}$. To determine the nitrogen $(\mathrm{N} \%)$ and carbon contents $(\mathrm{C} \%)$, an Elemental Combustion System 4010 CHNS-O analyser (Costech Instruments, Italy/USA) was used. The content of soluble carbohydrates was assessed as described by Haissig and Dickson [38] and Hansen and Møller [39] using methanol-chloroform-water extraction and the colour reaction with anthrone and spectrophotometric analysis at $\lambda=625 \mathrm{~nm}$. Starch content was measured in the precipitate remaining after the extraction of soluble carbohydrates at $\lambda=450 \mathrm{~nm}$ after a colour reaction with dianisidine. Both were expressed as percentages of the dry mass. The phenol content was expressed as $\mu \mathrm{M}$ chlorogenic acid g-1 d.m. after the use of Folin 
Ciocalteu's Phenol Reagent (Sigma F-9252) and spectrophotometric analysis $(1=660 \mathrm{~nm})$ according to Johnson and Schaal [40], as modified by Singleton and Rossi [41].

\subsection{Statistical Analyses}

After initial testing of residuals normality (Shapiro-Wilk test) and equal variance (Levene test), a mixed analysis of variance (ANOVA) model with restricted maximum likelihood (REML) was used to evaluate the influence of sex, fertilization, needle age, year, and season (fixed factors) and their interaction with nitrogen, carbon, $\mathrm{C} / \mathrm{N}$ ratio, $\mathrm{TPhC}$, $\mathrm{TNC}$, and starch content in the needles from the pot experiment. Parental tree and block nested within the year, and individuals nested within the season, block, and parental tree were random factors. Only two-way interactions were interpreted.

The second mixed ANOVA model for the same elements and metabolites was performed for the field study trees. Year, season, and gender were considered fixed factors, while individual, year in individual, and season in individual and year were considered random factors.

A Student's $t$ test was used to compare mean values between sexes. The results expressed as percentages were arcsin transformed for analyses by ANOVA. All analyses were performed using JMP software (version 15.0.0), SAS Institute, Cary, NC, USA.

\section{Results}

\subsection{Fertilization and Needle Age}

The fertilization treatment had a significant effect on the content of N, C, and phenolic compounds (TPhC) in needles (Table S1). The fertilized individuals had a higher nitrogen level (mean $2.670 \% \pm 0.028$ ) compared with the treatment without fertilizer $(1.827 \% \pm 0.030)$ and carbon $(49.85 \pm 0.148 ; 49.35 \pm 0.166$, respectively) and a lower level of TPhC (186.9 $\pm 4.782 ; 200.6 \pm 4.492$, respectively). There was no significant effect of fertilization on TNC and starch (Table S1). Chemical components did not show any significant interaction between fertilization and sex (Table S1) or between needle age and sex (Table S1). Therefore, the presented results show the total mean values for sexes, seasons, and years without separation of these variables.

\subsection{Sex}

The carbon level was very constant in all analysed variants. There was no evidence of a difference in carbon content between the sexes (Figure 1(A1,A2); Table S1).

In the field study (adult trees), sex had a clear effect on nitrogen content; mature females had lower nitrogen levels compared with males (Figure 1(B1)). The total mean nitrogen in the field study was $1.96 \% \pm 0.028$ for females and $2.19 \% \pm 0.029$ for males. No relationship was found between sex and nitrogen in the pot experiment. (Figure 1(B2)).

In the field study, sex did not affect the TNC content (Figure 1(C1)). In the pot experiment, however, females had significantly higher levels of TNC in spring and summer of the first year and autumn of the second year compared with males (Figure 1(C2)).

Females had significantly higher starch levels compared with males (total mean $=$ $128.0 \mathrm{mg} \times \mathrm{g}^{-1} \pm 0.060$ vs. $109.4 \mathrm{mg} \times \mathrm{g}^{-1} \pm 0.060$ ) in the field study (Figure 1(D1)) However, in the pot experiment, a significant sex-season interaction indicated variability in starch content between males and females (Figure 1(D2)). In males, the starch content was significantly higher in the summer and autumn in the first season and in females in the autumn and winter of the second season (Figure 1(D2)). 
Field experiment
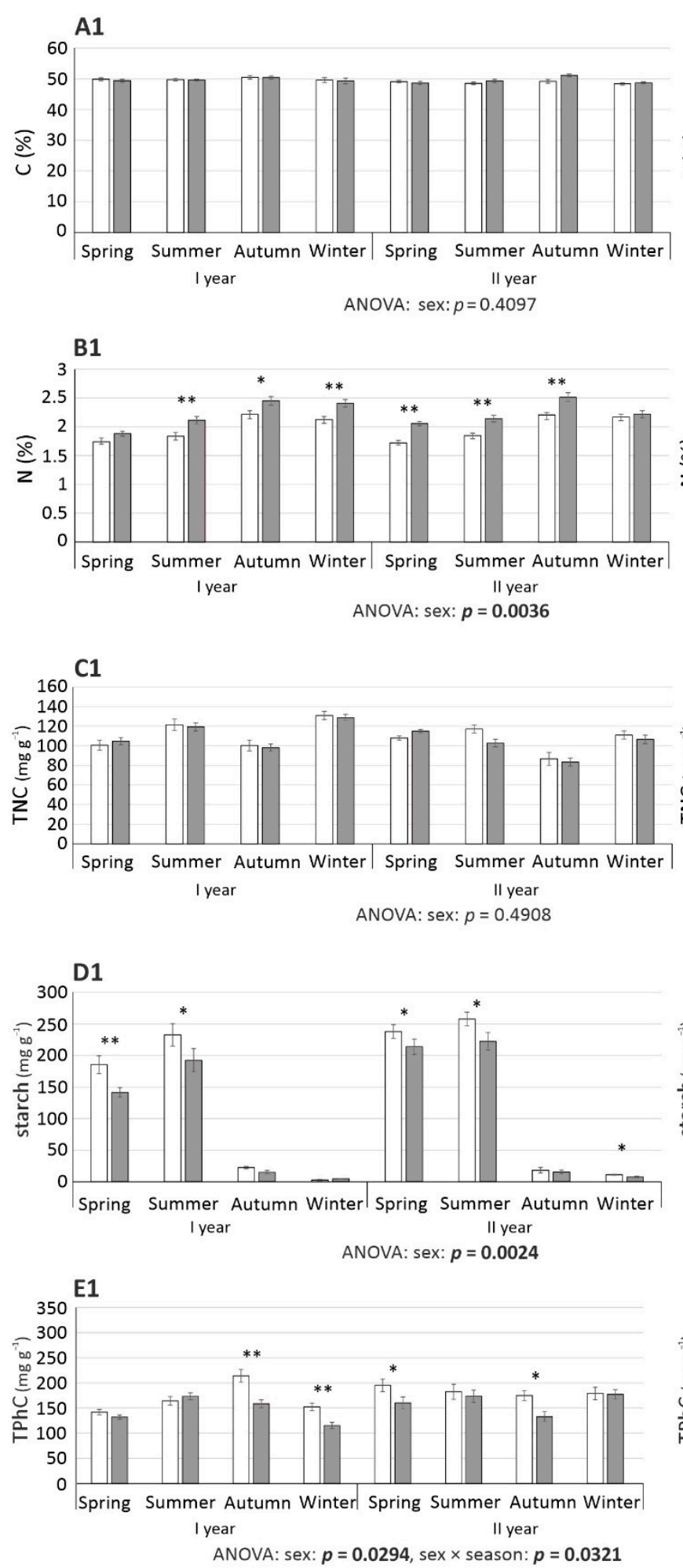

Pot experiment
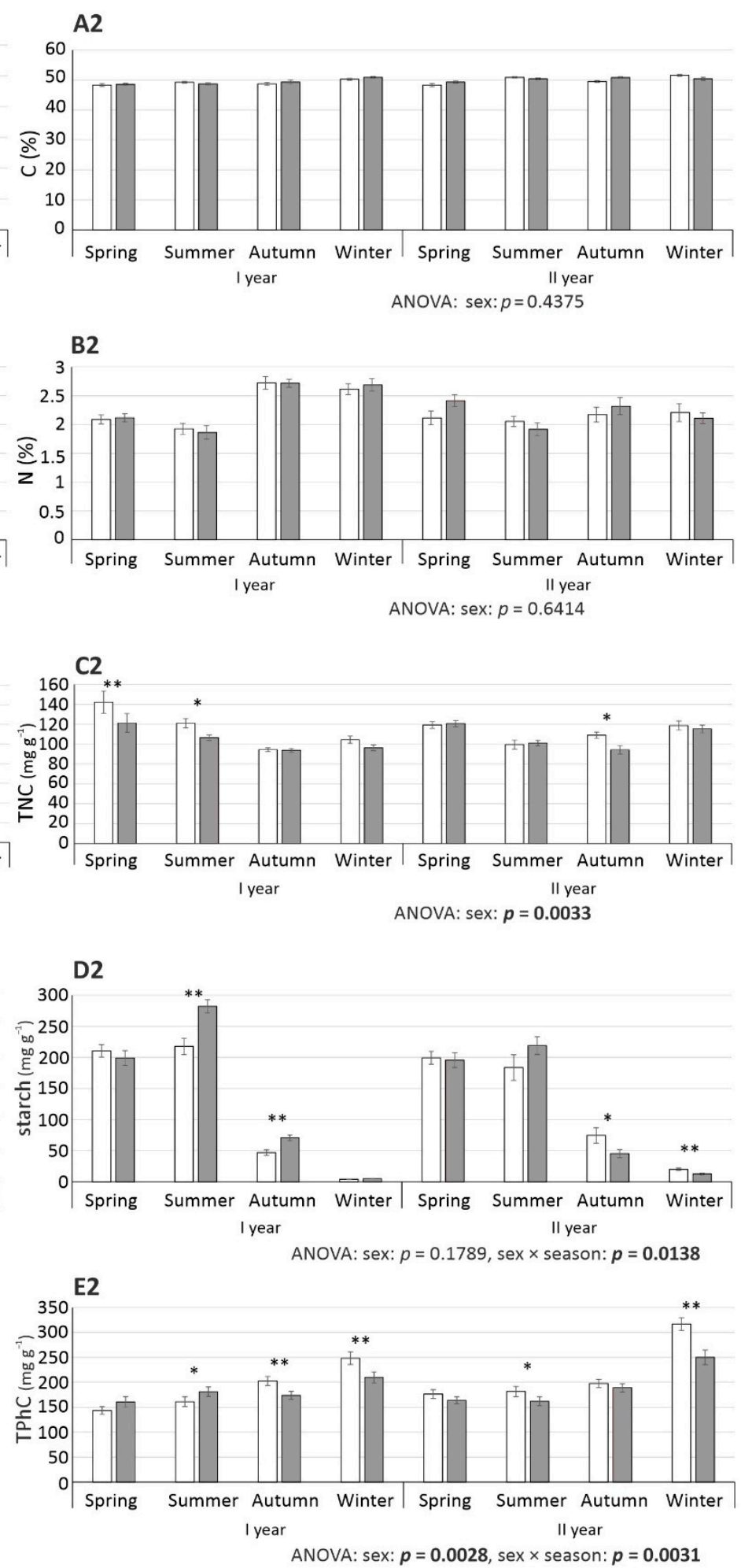

Figure 1. Mean ( \pm standard error) content of carbon (A), nitrogen (B), total non-structural carbohydrates (TNC) (C), starch (D), phenolic compounds (TPhC) (E) in Taxus baccata L. needles of female (white) and male (grey) individuals in the field experiment (1-left side) and the pot experiment (2-right side). Asterisks indicate statistical differences between males and females at ${ }^{*} p<0.05 ; * *<0.01$ (Student's $t$-test). See details in Table S1. 
Unlike the other analysed traits, female individuals had a higher level of TPhC both in field studies and pot experiment (Figure 1(E1,E2)). The total mean content in the field study was $171.6( \pm 4.183) \mathrm{mg} \times \mathrm{g}^{-1}$ for females and $157.0( \pm 4.284) \mathrm{mg} \times \mathrm{g}^{-1}$ for males. In the pot experiment the figures were $201.1( \pm 5.103) \mathrm{mg} \times \mathrm{g}^{-1}$ and $186.2( \pm 4.053) \mathrm{mg} \times \mathrm{g}^{-1}$, for females and males, respectively. On the first two dates of samplings, a slightly higher (significant only in the second date) level of TPhC was shown in males in the pot experiment. On other dates, females had a higher level of this compound, and significant differences were observed in summer, autumn, and winter of the first year and in summer and winter of the second year (Figure 1(E2)). The high level of TPhC under the pot experiment in winter in both analysed years also draws attention (Figure 1(E2)).

\section{Discussion}

Our research confirmed the rule that female individuals invest primarily in defence and storage $[5,6,13]$. As a result of this trade-off, males have more resources for growth, which was previously confirmed in natural populations of the common yew, where a higher radial growth rate of males [25] as well as height and diameter was demonstrated [26].

Female yew individuals had lower $\mathrm{N}$ and higher starch levels in the field study (adult trees), but this was not found in the pot experiment (juvenile trees). Since plants in the pot experiment had little or no reproductive effort, this indicates that the levels of these nutrients are related more to reproductive effort than to evolutionary adaptation. However, the higher levels of defensive substances in females may be triggered in the early stages of development, as the females had higher levels of these substances both in the pot experiment and under field studies. Since females contained higher levels of phenolic compounds (TPhC) in the adults and juveniles and had higher levels of starch in the adults, the first hypothesis may relate only to defence substances.

Higher starch levels were found in females in the field study, but under the controlled conditions in the pot experiment, starch levels were higher in females only at the last two sampling dates. This may indicate a delayed start to storage in females related to their longterm resources-storage strategy [42]. Similar results were obtained for the herbaceous vine Tinospora cordifolia [43], where female individuals had a higher level of starch compared with males. The higher nitrogen level in male leaves in mature specimens in the field study is the most frequently observed relationship in dioecious species [21,22,24,44,45]. This may be due to the increased nitrogen requirements of males associated with pollen production because of the high nitrogen content of the pollen grains $[9,46]$. On the other hand, higher carbohydrates levels in female individuals are associated with a greater demand for carbohydrates used in the production of seeds and associated structures, arils in the case of yew $[47,48]$.

The higher levels of TPhC in females in both the pot experiment and field study are interesting. Higher levels of defensive substances in female specimens are frequently observed in dioecious plants, confirming that females are better defended than males $[5,13,44,48-50]$. As in other studies, we did not find a significant effect of environmental conditions (in our case, fertilization) on males or females [51]. This could indicate a genetic determination of female defence strategies. However, different levels of $\mathrm{TPhC}$ were observed, particularly higher levels in males at the first two sampling dates (spring and summer) in juvenile plants (pot experiment). These two sampling dates were before individuals produced strobili. At later dates, strobili were already visible, and the level of TPhC was then higher in female individuals and similar to adult trees in the field study. While we have no proof that TPhC is genetically determined, it is significant that a larger investment in defence substances occurred very early in the ontogenesis of females. This may have been influenced by a potentially greater sensitivity of young trees to low temperature [52] since juveniles had a higher level of TPhC in winter in comparison with adult trees (Figure 1(E1,E2)). Moreover, the differences between the sexes in the pot experiment were greatest at that time. The effect of strobili production on juvenile plants also affected the TNC level, which was higher in females in the pot experiment mainly on the 
first two sampling dates and was not seen in mature plants in the field study. This suggests the existence of different innate features between the sexes, which resulted in marked differences between the first two sampling dates in TNC and TPhC. This SSD is backed-up by innate differences in morphology since females had a larger area of needles from the beginning of the pot experiment on the same plants [37] and in mature trees [24,26]. Lack of investment in generative organs, with a larger area of needles (or other features not identified in the research) may result in the observed greater mass of female plants in our study [37] and higher levels of TNC in female trees and higher level of TPhC in males in the first two dates. A larger mass is commonly observed in young female plants in dioecious species, where there is no or reduced level of resources for reproduction $[16,17,53]$.

Differentiation of TPhC levels across the seasons confirms our second hypothesis that the level of phenol compounds depends on the phenological stage. No such relationships were found in the other analysed compound and elements (Table S1). The significant interaction in the case of sex and season in the pot experiment (Figure 1(E2)) discussed above is interpreted as differences resulting from the maturation process of juvenile individuals.

The third research hypothesis that SSD would be greater in un-fertilized compared with fertile conditions was rejected since no interactions between sex and fertilization were found, which indicated a similar response of male and female plants under conditions of varying nutrient availability. However, it has been shown that under $\mathrm{N}$ deficiency, there was more starch accumulation in females than in males in Populus catahayana [54] and Ginkgo biloba [55]. This may be attributed to the small reproductive effort of the juveniles in our pot experiment since the ratio of generative organ to needles and stems mass was several times lower in the juveniles compared with the mature individuals [37]. Nevertheless, once juveniles started producing strobili, the females had higher levels of $\mathrm{TPhC}$, regardless of fertilization.

\section{Conclusions}

In summary, adult yews showed chemistry characteristics typical for dioecious species: female individuals had higher levels of storage (starch) and defence substances (phenolics), and male individuals had a higher level of $\mathrm{N}$ necessary for pollen production. This confirms previous research that Taxus baccata L. is a good model species for SSD analysis. However, this is the first time that it has been shown that female juveniles, like adults, had a higher level of defence substances. This may indicate a priority in applying defence of female individuals. The lack of fertilization effect on sex-specific variation may be the consequence of a lower reproductive effort of juveniles in the pot experiment.

Supplementary Materials: The following are available online at https:/ /www.mdpi.com/article/10 $.3390 / \mathrm{f12070844/s1,} \mathrm{Table} \mathrm{S1.} \mathrm{Taxus} \mathrm{baccata} \mathrm{(L.)} \mathrm{full} \mathrm{factorial} \mathrm{ANOVA} \mathrm{results} \mathrm{for} \mathrm{pot} \mathrm{experiment} \mathrm{and}$ field experiment for nitrogen, carbon, $\mathrm{C} / \mathrm{N}$ ratio, total nonstructural carbohydrates (TNC), starch and total phenolic compounds (TPhC). Figure S1. Photo of Taxus baccata (L.) cuttings in pot experiment in 2013. Figure S2. Photo of Taxus baccata (L.) cuttings in pot experiment in 2015.

Author Contributions: Conceptualization, K.N., G.I., E.P.-K., and M.J.G.; methodology, K.N., G.I., E.P.-K., and M.J.G.; formal analysis, K.N. and M.J.G.; investigation, K.N., G.I., and M.J.G.; writingoriginal draft preparation, K.N.; writing—review and editing, K.N., G.I., E.P.-K., M.J.G., and P.A.T.; supervision, G.I., E.P.-K., M.J.G., and P.A.T.; funding acquisition, G.I. All authors have read and agreed to the published version of the manuscript.

Funding: The project was financed by the Polish National Science Centre, awarded based on decision number DEC-2012/07/B/NZ9/01314, and was financially supported by the Institute of Dendrology, Polish Academy of Sciences, Kórnik, Poland.

Institutional Review Board Statement: Not applicable.

Informed Consent Statement: Not applicable.

Data Availability Statement: Not applicable. 
Acknowledgments: The authors thank Mariola Rabska and Andrzej M. Jagodziński for helpful comments and Stanisław Zymon for help during rooting shoots.

Conflicts of Interest: The authors declare no conflict of interest. The funders had no role in the design of the study; in the collection, analyses, or interpretation of data; in the writing of the manuscript; or in the decision to publish the results.

\section{References}

1. Renner, S.S.; Ricklefs, R.E. Dioecy and its correlates in the flowering plants. Am. J. Bot. 1995, 596-606. [CrossRef]

2. Weiblen, G.D.; Oyama, R.K.; Donoghue, M.J. Phylogenetic analysis of dioecy in monocotyledons. Am. Nat. 2000, 155, 46-58. [CrossRef] [PubMed]

3. Renner, S.S. The relative and absolute frequencies of angiosperm sexual systems: Dioecy, monoecy, gynodioecy, and an updated online database. Am. J. Bot. 2014, 101, 1588-1596. [CrossRef]

4. Walas, Ł.; Mandryk, W.; Thomas, P.A.; Tyrała-Wierucka, Ż.; Iszkuło, G. Sexual systems in gymnosperms: A Review. Basic Appl. Ecol. 2018, 31, 1-9. [CrossRef]

5. Randriamanana, T.R.; Nybakken, L.; Lavola, A.; Aphalo, P.J.; Nissinen, K.; Julkunen-Tiitto, R. Sex-related differences in growth and carbon allocation to defence in Populus tremula as explained by current plant defence theories. Tree Physiol. 2014, 34, 471-487. [CrossRef]

6. Geber, M.A. Theories of the evolution of sexual dimorphism. In Gender and Sexual Dimorphism in Flowering Plants; Geber, P.D.M.A., Dawson, P.D.T.E., Delph, P.D.L.F., Eds.; Springer: Berlin/Heidelberg, Germany, 1999; pp. 97-122.

7. Levins, R. Evolution in Changing Environments: Some Theoretical Explorations; (MPB-2); Princeton University Press: Princeton, NJ, USA, 1968; ISBN 978-0-691-07959-2.

8. Obeso, J.R. The Costs of reproduction in plants. New Phytol. 2002, 155, 321-348. [CrossRef]

9. Dawson, T.E.; Geber, M.A. Sexual dimorphism in physiology and morphology. In Gender and Sexual Dimorphism in Flowering Plants; Geber, P.D.M.A., Dawson, P.D.T.E., Delph, P.D.L.F., Eds.; Springer: Berlin/Heidelberg, Germany, 1999 ; pp. $175-215$.

10. Case, A.L.; Ashman, T.-L. 5-Sex-specific physiology and its implications for the cost of reproduction. In Reproductive Allocation in Plants; Physiological Ecology; Reekie, E.G., Bazzaz, F.A., Eds.; Academic Press: Burlington, ON, Canada, 2005 ; pp. $129-157$.

11. Álvarez-Cansino, L.; Zunzunegui, M.; Díaz Barradas, M.C.; Esquivias, M.P. Gender-specific costs of reproduction on vegetative growth and physiological performance in the dioecious shrub Corema album. Ann. Bot. 2010, 106, 989-998. [CrossRef]

12. Lloyd, D.G.; Webb, C.J. Secondary sex characters in plants. Bot. Rev. 1977, 43, 177-216. [CrossRef]

13. He, Y.; Zhu, Z.; Guo, Q.; Xia, Z. Sex-Specific interactions affect foliar defense compound accumulation and resistance to herbivores in Populus cathayana. Sci. Total Environ. 2021, 774, 145819. [CrossRef]

14. Purrington, C.B.; Schmitt, J. Sexual dimorphism of dormancy and survivorship in buried seeds of Silene latifolia. J. Ecol. 1995, 83, 795-800. [CrossRef]

15. Delph, L.F.; Meagher, T.R. Sexual dimorphism masks life history trade-offs in the dioecious plant Silene latifolia. Ecology 1995, 76, 775-785. [CrossRef]

16. Nicotra, A.B. Sexually dimorphic growth in the dioecious tropical shrub, Siparuna grandiflora. Funct. Ecol. 1999, 13, 322-331. [CrossRef]

17. Cipollini, M.L.; Dingley, N.R.; Felch, P.; Bailey, N.J.; Moss, J.P.; Gaskin, M.G.; Williams, S. Does sex ratio bias and sexual dimorphism occur in Lindera benzoin L. (Lauraceae) prior to fruit Production? J. Torrey Bot. Soc. 2020, 147, 272-280. [CrossRef]

18. Retuerto, R.; Sánchez Vilas, J.; Varga, S. Sexual dimorphism in response to stress. Environ. Exp. Bot. 2018, 146, 1-4. [CrossRef]

19. Li, Z.; Wu, N.; Liu, T.; Tang, M.; Chen, H. Gender-related responses of dioecious plant Populus cathayana to AMF, drought and planting pattern. Sci. Rep. 2020, 10, 11530. [CrossRef] [PubMed]

20. Dawson, T.E.; Ehleringer, J.R. Gender-specific physiology, carbon isotope discrimination, and habitat distribution in boxelder, Acer negundo. Ecology 1993, 74, 798-815. [CrossRef]

21. Chen, L.; Dong, T.; Duan, B. Sex-specific carbon and nitrogen partitioning under N deposition in Populus cathayana. Trees 2014, 28, 793-806. [CrossRef]

22. Agren, J. Sexual differences in biomass and nutrient allocation in the dioecious Rubus chamaemorus. Ecology 1988, 69, 962. [CrossRef]

23. Seger, J.; Eckhart, V.M. Evolution of sexual systems and sex allocation in plants when growth and reproduction overlap. Proc. R. Soc. B Biol. Sci. 1996, 263, 833-841. [CrossRef]

24. Nowak-Dyjeta, K.; Giertych, M.J.; Thomas, P.; Iszkuło, G. Males and females of Juniperus communis L. and Taxus baccata L. show different seasonal patterns of nitrogen and carbon content in needles. Acta Physiol. Plant. 2017, 39, 191. [CrossRef]

25. Cedro, A.; Iszkulo, G. Do females differ from males of European yew (Taxus baccata L.) in dendrochronological analysis? Tree Ring Res. 2011, 67, 3-11. [CrossRef]

26. Iszkuło, G.; Jasińska, A.K.; Giertych, M.J.; Boratyński, A. Do secondary sexual dimorphism and female intolerance to drought influence the sex ratio and extinction risk of Taxus baccata? Plant Ecol. 2009, 200, 229-240. [CrossRef]

27. Vessella, F.; Salis, A.; Scirè, M.; Piovesan, G.; Schirone, B. Natural regeneration and gender-specific spatial pattern of Taxus baccata in an old-growth population in Foresta Umbra (Italy). Dendrobiology 2015, 73, 75-90. [CrossRef] 
28. Robakowski, P.; Pers-Kamczyc, E.; Ratajczak, E.; Thomas, P.A.; Ye, Z.-P.; Rabska, M.; Iszkuło, G. Photochemistry and antioxidative capacity of female and male Taxus baccata L. acclimated to different nutritional environments. Front. Plant Sci. 2018, 9, 742. [CrossRef] [PubMed]

29. Greenwood, M.S. Rejuvenation of Forest Trees. In Hormonal Control of Tree Growth: Proceedings of the Physiology Working Group Technical Session, Society of American Foresters National Convention, Birmingham, AL, USA, 6-9 October 1986; Forestry Sciences; Kossuth, S.V., Ross, S.D., Eds.; Springer: Dordrecht, The Netherlands, 1987; pp. 1-12. ISBN 978-94-017-1793-9.

30. Klimeš, L.; Klimešová, J.; Hendriks, R.; van Groenendael, J. Clonal plant architecture: A comparative analysis of form and function. In The Ecology and Evolution of Clonal Plants; de Kroon, H., van Groenendael, H., Eds.; Backhuys: Leiden, The Netherlands, 1997; pp. 1-29.

31. Åhman, I. Growth, Herbivory and disease in relation to gender in Salix viminalis L. Oecologia 1997, 111, 61-68. [CrossRef]

32. Nybakken, L.; Hörkkä, R.; Julkunen-Tiitto, R. Combined enhancements of temperature and UVB influence growth and phenolics in clones of the sexually dimorphic Salix myrsinifolia. Physiol. Plant. 2012, 145, 551-564. [CrossRef]

33. Konatowska, M.; Rutkowski, P.; Budka, A.; Goliński, P.; Szentner, K.; Mleczek, M. The interactions between habitat, sex, biomass and leaf traits of different Willow (Salix) Genotypes. Int. J. Environ. Res. 2021, 15, 395-412. [CrossRef]

34. Påhlsson, A.-M.B. Influence of aluminium on biomass, nutrients, soluble carbohydrates and phenols in beech (Fagus sylvatica). Physiol. Plant. 1990, 78, 79-84. [CrossRef]

35. Veteli, T.O.; Mattson, W.J.; Niemelä, P.; Julkunen-Tiitto, R.; Kellomäki, S.; Kuokkanen, K.; Lavola, A. Do elevated temperature and CO2 generally have counteracting effects on phenolic phytochemistry of boreal trees? J. Chem. Ecol. 2007, 33, 287-296. [CrossRef]

36. Messier, C.; Puttonen, P. Spatial and temporal variation in the bight bnvironment of developing scots pine stands: The Basis for a quick and efficient method of characterizing bight. Can. J. For. Res. 1995, 25, 343-354. [CrossRef]

37. Nowak, K.; Giertych, M.J.; Pers-Kamczyc, E.; Thomas, P.A.; Iszkuło, G. Rich but not poor conditions determine sex-specific differences in growth rate of juvenile dioecious plants. J. Plant Res. 2021, 33, 287-296.

38. Haissig, B.E.; Dickson, R.E. Starch measurement in plant tissue using enzymatic hydrolysis. Physiol. Plant. 1979, 47, 151-157. [CrossRef]

39. Hansen, J.; Møller, I. Percolation of starch and soluble carbohydrates from plant tissue for quantitative determination with anthrone. Anal. Biochem. 1975, 68, 87-94. [CrossRef]

40. Johnson, G.; Schaal, L.A. Accumulation of phenolic substances and ascorbic acid in potato tuber tissue upon injury and their possible role in disease resistance. Am. Potato J. 1957, 34, 200-209. [CrossRef]

41. Singleton, V.L.; Rossi, J.A. Colorimetry of total phenolics with phosphomolybdic-phosphotungstic acid reagents. Am. J. Enol. Vitic. 1965, 16, 144-158.

42. Montesinos, D.; Villar-Salvador, P.; García-Fayos, P.; Verdú, M. Genders in Juniperus thurifera have different functional responses to variations in nutrient availability. New Phytol. 2012, 193, 705-712. [CrossRef]

43. Choudhry, N.; Singh, S.; Siddiqui, M.B.; Khatoon, S. Impact of seasons and dioecy on therapeutic phytoconstituents of Tinospora cordifolia, a Rasayana drug. BioMed Res. Int. 2014, 2014, e902138. [CrossRef]

44. Rabska, M.; Pers-Kamczyc, E.; Żytkowiak, R.; Adamczyk, D.; Iszkuło, G. Sexual dimorphism in the chemical composition of male and female in the dioecious tree, Juniperus communis L., growing under different nutritional conditions. Int. J. Mol. Sci. 2020, 16, 8094. [CrossRef]

45. Rabska, M.; Warwick, N.W.M.; Iszkuło, G.; Gross, C.L. Intersexual differences in leaf size and shape in dioecious Adriana tomentosa (Euphorbiaceae). J. Plant Ecol. 2021, 14, 67-83. [CrossRef]

46. Rabie, A.L.; Wells, J.D.; Dent, L.K. The nitrogen content of pollen protein. J. Apic. Res. 1983, 22, 119-123. [CrossRef]

47. Wallace, C.S.; Rundel, P.W. Sexual dimorphism and resource allocation in male and female shrubs of Simmondsia chinensis. Oecologia 1979, 44, 34-39. [CrossRef]

48. Blake-Mahmud, J.; Struwe, L. When the going gets tough, the tough turn female: Injury and sex expression in a sex-changing tree. Am. J. Bot. 2020, 107, 339-349. [CrossRef]

49. Elmqvist, T.; Cates, R.G.; Harper, J.K.; Gardfjell, H. Flowering in males and females of a Utah willow, Salix rigida and effects on growth, tannins, phenolic glycosides and sugars. Oikos 1991, 61, 65-72. [CrossRef]

50. Randriamanana, T.R.; Nissinen, K.; Moilanen, J.; Nybakken, L.; Julkunen-Tiitto, R. Long-term UV-B and temperature enhancements suggest that females of Salix myrsinifolia plants are more tolerant to UV-B than males. Environ. Exp. Bot. 2015, 109, 296-305. [CrossRef]

51. Miljković, D.; Selaković, S.; Vujić, V.; Stanisavljević, N.; Radović, S.; Cvetković, D. Patterns of herbivore damage, developmental stability, moisrphological and biochemcal traits in female and male Mercurialis perennis in contrasting light habitats. Alp. Bot. 2018, 128, 193-206. [CrossRef]

52. Vitasse, Y.; Lenz, A.; Hoch, G.; Körner, C. Earlier leaf-out rather than difference in freezing resistance puts juvenile trees at greater risk of damage than adult trees. J. Ecol. 2014, 102, 981-988. [CrossRef]

53. Nybakken, L.; Julkunen-Tiitto, R. Gender differences in Salix myrsinifolia at the pre-reproductive stage are little affected by simulated climatic change. Physiol. Plant. 2013, 147, 465-476. [CrossRef] [PubMed]

54. Zhang, S.; Jiang, H.; Zhao, H.; Korpelainen, H.; Li, C. Sexually different physiological responses of Populus cathayana to nitrogen and phosphorus deficiencies. Tree Physiol. 2014, 34, 343-354. [CrossRef] [PubMed]

55. He, M.; Shi, D.; Wei, X.; Hu, Y.; Wang, T.; Xie, Y. Gender-related differences in adaptability to drought stress in the dioecious tree Ginkgo biloba. Acta Physiol. Plant. 2016, 38, 124. [CrossRef] 